\title{
Jack Goodall (1892-1980), ornithologist and artist of "Las aves de Chile": Some biographical notes
}

Jack Goodall (1892-1980), ornitólogo y artista de "Las aves de Chile”: Algunas notas biográficas

\author{
C. STUART HOUSTON ${ }^{1}$, FABIAN M. JAKSIC ${ }^{2, ~}{ }^{*} \&$ E. CHARLES NELSON ${ }^{3}$ \\ 1863 University Drive, Saskatoon, SK S7N 0J8, Canada \\ ${ }^{2}$ Center for Advanced Studies in Ecology and Biodiversity (CASEB), Pontificia Universidad Católica de Chile, \\ PO Box 114-D, Santiago, Chile \\ ${ }^{3}$ Tippitiwitchet Cottage, Hall Road, Outwell, Wisbech, PE14 8PE, United Kingdom \\ ${ }^{\star}$ Corresponding author: fjaksic@bio.puc.cl
}

William Jack Davies Goodall, “one of the three pioneers of modern Chilean ornithology" (Vuilleumier 2006), a Corresponding Fellow of the American Ornithologists' Union (AOU) (Wolfson 1953) and co-recipient of the AOU's Brewster Memorial Award in 1973 (Banks 1974), was born on 13 September 1892 at his parents' home, St. Jean d'Acre Cottage, Kings Road, Bembridge on the Isle of Wight, England (certified copy of an entry in register, Isle of Wight [FD 968782, 15 September 2010]). By April 1911, when he signed the Census Schedule for 52 Oxford Gardens, North Kensington, London (see below), he had dropped his first name and thereafter was known generally as Jack (Davies) Goodall. Although Goodall lived most of his life in Chile, a country with a strong Spanish influence where an individual uses a two-name "surname" - the first being the father's and the second the mother's - there is no known basis for Vuilleumier's (2006) indication that he ever used the name "Jack Goodall Callaway".

Jack's father was William Henry Goodall (born c. 1855) (the surname was sometimes spelled Goodhall in the mid-1800s), who gave his occupation as "scientific chemist" when his son's birth was registered. Jack's mother was Alma Louise Callaway (born c. 1859). William Henry Goodall and Alma Callaway were married in 1883 in St. Helens, Isle of Wight. The 1911 English census returns indicates that the couple had been married for 27 years and had had four children. The eldest, our subject William Jack Davies Goodall, born nine years after his parents married, was followed by three sisters: Luisa Mary, Frances Josefina and Almita Bessie. It is noteworthy that in 1901, at least on Census Day, Mrs. Alma Goodall and her three daughters were at 134 St. Helens Green, home of her elderly parents, William and Henrietta Callaway. At the same time, William Jack D. Goodall (then aged eight) was also not staying with either of his parents but was listed at his aunt's house at 12 St. Helens Green. She was Fanny H. Seymour, a widow aged 43 "living on (her) own means" with her daughters Marie and Cecily.

A decade later, on Census Day, Sunday 2 April 1911, Jack was again away from the family home studying to be a naval architect (the profession of one of his uncles, Frank Clement Goodall), and "passed the night" at 52 Oxford Gardens, North Kensington, west London. He filled in the return for the house and signed it. Jack listed himself as "nephew", because the owner of 52 Oxford Gardens was another uncle, Jeremiah Matthews Goodall FZS (18621939) also of The Nest, Bembridge. Jeremiah was probably a most influential person in Jack Goodall's life, more so than his own father or his uncle Frank, although the evidence is entirely circumstantial. J. M. Goodall was a founding member of the Isle of Wight Natural History Society in 1919 and one of its original vice-presidents (L. Snow, pers. comm.). He was especially interested in birds' eggs (Cole $\&$ Trobe 2000) and made several collecting trips in Argentina; it is possible that the main purpose of his visits to Argentina was business, 
not natural history, and that he merely took the opportunity to collect specimens while there.

Jack Goodall did not become a naval architect: no record can be traced of Goodall's enrollment in a relevant course in London, and he did not become a member of The Royal Institution of Naval Architects (Mrs. S. Charity, pers. comm.). Instead, he emigrated to Iquique in Chile having obtained, through an uncle, a job with Compañía Agua Santa, a nitrate production company. He arrived in Chile, via Argentina, late in 1912. Possibly he was the "J. Goodall, adult of 12 years and upwards, not accompanied by husband or wife" who, according to "Names and descriptions of British passengers embarked at the Port of Southampton" (The National Archives, London: BT27/782) for the Royal Mail Steam Packet Company's ship Vauban, took passage for Buenos Aires on 26 July 1912 from Southampton. It is known that Goodall arrived in Iquique about the same time Alfred William Johnson (1894-1979) (Schlatter et al. 1980), later to be his principal co-worker on Chilean birds. Neither Goodall nor Johnson enlisted in the British Army during the First World War I, and there are no traces of Goodall in Britain between 1911 and 1919. According to Bryan Johnson (pers. comm.), Alfred Johnson's son, "Goodall lived permanently in Chile ... He traveled to England on vacation approximately every 5 to 10 years for short periods of not more than a month at a time."

On 11 October 1919, after what was probably his first visit back to England, Jack Davies Goodall left Liverpool on the Pacific Steam Navigation Company's ship Ebro, returning to Chile by way of the Panama Canal. In "Names and descriptions of British passengers embarked at the Port of Liverpool" (The National Archives, London: BT27/899), Goodall's age was recorded as 27 years old, his occupation was given as "Manufacturer", and he was apparently travelling by himself. Under "Country of last Permanent Residence" was written, "Foreign Countries".

While Goodall was an accountant or book keeper for Compañía Agua Santa, Johnson worked as a time-keeper and by 1925 became general manager. After the company's mine closed following the Great Depression, both Johnson and Goodall moved south to Santiago. In 1931, Johnson, with Goodall as a minority partner, became involved in the Katz-Johnson refrigeration company (later named Frio-Lux Refrigeración S.A.I.). They also took over a bankrupt ice-cream company, Hayskrim S.A. ("ice cream"). Johnson remained Managing Director of Frio-Lux until 1967.

Jack Goodall spent his final two years in an old peoples' home. He died in Santiago on 30 December 1980, aged 88, and was buried in Zapallar (Houston 1999, Vuilleumier 2006) beside his former business partner and coauthor, Alfred Johnson; their graves are in the same plot close to the Pacific Ocean (Fig. 1) (Nelson 2011: 20). It is noteworthy that the third of the authors of "Las aves de Chile", and the first of the trio to die, Dr. Rodulfo Amando Philippi Bañados (1905-1969) (Johnson 1970), was also buried in the same cemetery.

Bryan Johnson (pers. comm.) recalled Jack Goodall: "Uncle Jack, as I called him, was a bachelor all his life, although he had many friends and led an active social life. He had good eyesight and hearing and infinite patience in finding birds' nests. He was quiet, extremely conservative, a very private man."

The first volume of "Las aves de Chile" illustrated with paintings by Goodall was published in 1946 (Goodall et al. 1946, Zimmer 1947, Vuilleumier 2006). The text was written largely by Johnson while Philippi was responsible for the information about the skins collections and measurements. The second volume was issued in 1951 and two supplements followed. A second, updated edition was prepared in the early 1960 s by Johnson, with Goodall's cooperation, and published in English (Johnson \& Goodall 1965-1967; see Eisenmann 1968). Before "Las aves de Chile" by Goodall and his co-authors, there were only three relevant works available on Chilean ornithology: Wetmore (1926) and Hellmayr (1932) had concentrated on taxonomy, phylogeny, and geographical distribution, whereas Housse (1945) had emphasized natural history. Goodall, Johnson and Philippi bridged the gaps brilliantly, providing the first unified treatise on the birds of Chile. In addition, they reported a substantial amount of new information, especially about nests and eggs, which has stood the test of time. All three authors were elected Corresponding Fellows at the $70^{\text {th }}$ stated meeting of the AOU, held in Baton Rouge, Louisiana, in 1952 (Wolfson 1953). 

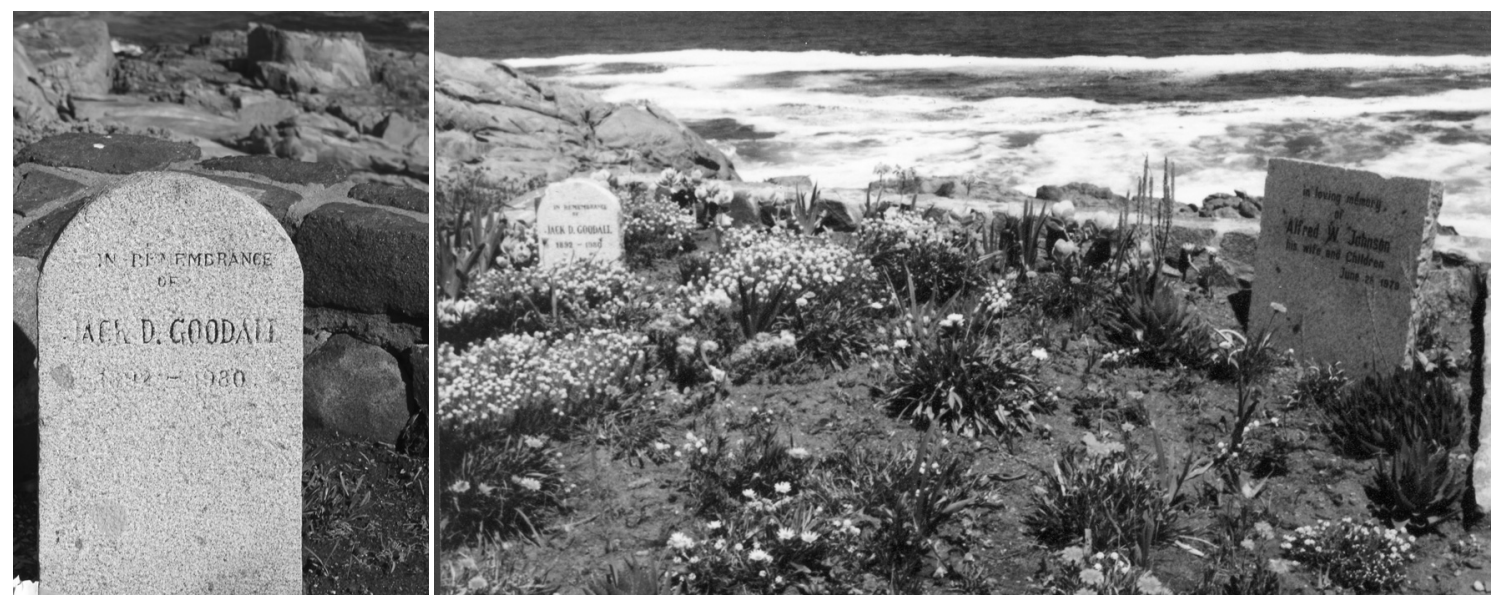

Fig. 1: Tumba de Jack Goodall en Zapallar; a la izquierda una fotografía de la lápida grabada (cortesía de Agustín Iriarte, julio de 2011); a la derecha el sitio de la sepultura de Goodall junto a la de Alfred Johnson, fotografiado a fines de los 1980's (cortesía de Marlore y Bryan Johnson).

Jack Goodall's grave in Zapallar; left: the engraved tombstone (July 2011, courtesy of Agustin Iriarte); right: the site of Goodall's grave with that of Alfred Johnson photographed in the late 1980s (courtesy of Marlore and Bryan Johnson).

ACKNOWLEDGMENTS: For assistance in unravelling the early life of Jack Goodall we are most grateful to Lorna Snow (Secretary, Isle of Wight Natural History and Archaeological Society), David Evans, and especially Bryan and Marlore Johnson. For recent photographs of the graves of Goodall, Johnson and Philippi in Zapallar cemetery we are indebted to Dr. Pablo Donoso, Alberto Nightingale and Agustín Iriarte.

\section{LITERATURE CITED}

BANKS RC (1974) Proceedings of the $91^{\text {st }}$ stated meeting of the AOU, Provincetown Cape Cod MA, 8-12 Oct 1973. Auk 91: 387-410.

COLE AC \& WM TROBE (2000) The egg collectors of Great Britain and Ireland. Peregrine Press, Leeds, UK.

EISENMANN E (1968) (Review) Birds of Chile and adjacent regions of Argentina, Bolivia and Peru, vol. 2. By AW Johnson (in English). Auk 85: 524-525.

GOODALL JD, AW JOHNSON \& RA PHILIPPI BAÑADOS (1946-1951) Las aves de Chile, su conocimiento y sus costumbres. Two volumes. Platt Establecimientos Gráficos, Buenos Aires, Argentina.

HELLMAYR CE (1932) The birds of Chile. Field Museum of Natural History, Zoological Series 19: 1-472.

HOUSSE R (1945) Las aves de Chile en su clasificación moderna: su vida y sus costumbres. Ediciones Universidad de Chile, Santiago.
HOUSTON CS (1999) Notes and queries, 31: J. D. Goodall. Society for the History of Natural History newsletter, series 2, no. 66: 11 (reprinted in Nelson [2011] p. 20).

JOHNSON AW \& JD GOODALL (1965-1967) The birds of Chile and adjacent regions of Argentina, Bolivia, and Peru. Two volumes. Platt Establecimientos Gráficos, Buenos Aires, Argentina.

JOHNSON AW (1970) Rodulfo Amando Philippi B. (M.D.). Obituary. Auk 87: 862-863.

NELSON EC (ed) (2011) History and mystery. Notes and queries from the newsletters of the Society for the History of Natural History. Society for the History of Natural History, London, UK.

SCHLATTER RP, B ARAYA \& P MILLIE (1980) Alfred W. Johnson, O.B.E. Ibis 122: 373-374.

VUILLEUMEIR F (2006) In memoriam: Jack Davies Goodall Callaway (Galloway?), 1892 (1893?)-1980. Auk 123: 594-595.

WETMORE A (1926) Observations on the birds of Argentina, Paraguay, Uruguay, and Chile. Smithsonian Institution Bulletin 133: 1-448.

WOLFSON A (1953) The $70^{\text {th }}$ stated meeting of the AOU, Baton Rouge, Louisiana, 20-24 Oct. 1952. Auk 70: 183-195.

ZIMMER JT (1947) (Review) Birds of Chile, volume 1, in Spanish. Auk 64: 149. 
